www.jmscr.igmpublication.org Impact Factor 5.244

Index Copernicus Value: 83.27 ISSN (e)-2347-176x ISSN (p) 2455-0450 crossref DOI:_https://dx.doi.org/10.18535/jmscr/v4i12.120

\title{
A Study of Clinicomorphological Profile of Ovarian Tumors in Western India
}

Authors

\section{Dr Shaheen H. Kanpurwala, Dr Shantanu M. Chavan, Dr Sugam Agrawal}

Department of Pathology, Grant Government Medical College \& Sir J J Group of Hospitals, Byculla East, Mumbai 400008, Maharashtra

Corresponding Author

\section{Dr Sugam Agrawal}

Blood Bank, Sir J J Group of Hospitals, Byculla East, Mumbai 400008

Email: drsugamagrawal2487@gmail.com,shk.mumbai@yahoo.com, Phoneno.8691007327

\begin{abstract}
Background: Ovarian tumors are one of the common tumors of female genital tract. The clinical and morphological features of these tumors are variable and also vary with geographic region.

Aim: The aim of study is collection and analysis of data of various clinicomorphological features of ovarian tumors in light of various studies conducted in variable geographic regions.

Results: Age group with peak incidence was 21-40 years. Abdominal pain was the most common symptom (68.8\%). Tumors were bilateral in $12.7 \%$ patients. Malignant and borderline tumors had a larger mean diameter $(>10 \mathrm{~cm})$ as compared to benign tumors $(<10 \mathrm{~cm})$. Grossly tumors were most commonly cystic (63.7\%). Benign tumors were most common (57.32\%) followed by malignant (35.66\%) and borderline tumors (7\%). Serous cystadenoma (35.88\%), Borderline mucinous (63.6\%) and Serous cystadenocarcinoma (46.4\%) were the commonest tumors in benign, borderline and malignant categories respectively. Among histopathological types Surface epithelial tumors (70.07\%) were the commonest followed by Germ cell tumors (22.29\%), Sex cord stromal tumors (5.09\%) and metastatic tumors (2.55\%).

Conclusion: In our study, conducted in Western India, clinically lower abdominal pain was the most common symptom in contrast to Western countries wherein abdominal distension was most common. Benign tumors were most common but the incidence of borderline and malignant tumors were proportionately higher when compared to Western nations. Surface epithelial tumors were most common in both benign and malignant categories. Serous cystadenomas, Mucinous borderline and Serous cystadenocarcinoma were the most common tumors in benign, borderline and malignant categories respectively. These findings are important geographical variations since different tumors have been reported to be the commonest in benign, borderline and malignant categories in studies conducted in different geographic areas.

KEYWORDS - Ovarian tumor, incidence, histopathology, Western India.
\end{abstract}

\section{INTRODUCTION}

Tumors of the ovary are common forms of neoplasia in women. Among cancers of the female genital tract, the ovarian cancers are the most common cancers. They are the sixth most common form of cancer in women in the United 
States. ${ }^{1}$ However, the clinical and pathological characteristics are wide and variable for ovarian tumors. $^{2}$ Because many of this ovarian neoplasms cannot be detected early in the development especially in developing nations, they account for a disproportionate number of deaths from cancer of the female genital tract. A detailed study was performed over duration of 3 years and 9 months to study all clinically and pathologically relevant aspects of ovarian tumors.

\section{MATERIAL AND METHODS}

A prospective and retrospective study of ovarian tumors was done in our institute. Specimen was received in $10 \%$ formalin. Relevant clinical data was obtained from the requisition forms sent along with the specimens and from the record section of the institute. Specimen received was studied thoroughly to note the gross findings. Specimens underwent routine processing. The sections were taken from necessary sites. In cystic lesions all the locules opened and character of fluid examined. Paraffin blocks were prepared and cut. Slides prepared and stained with routine hematoxyline and eosin stain. Special stains were used wherever applicable. All the observations recorded, analyzed and classified as per WHO classification .All findings and details tabulated and interpretation done .

\section{RESULTS}

There were a total of 157 cases of ovarian tumors from Jan 2007 to Sept 2010 in our institute. There were total 5046 samples of gynaecological patients in our tertiary care hospital. Thus the overall incidence of ovarian tumors was $3.10 \%$.

The age range was 11 to 72 years. The surface epithelial tumours and sex cord stromal tumors were commoner in and above the $4^{\text {th }}$ decade. A lower mean age was observed for germ cell tumors (age range of 11 to 42 years) - 24.2 years for dysgerminoma, 30.6 years for mature cystic teratoma and 16 years for immature teratoma.
Clinically, most of the ovarian tumors presented with lower abdominal pain. Of 157 cases, 108 cases $(68.78 \%$ ) presented with lower abdominal pain. Other presenting symptoms were low in incidence accounting for small percentage of cases, like lump in abdomen (12 cases or $7.6 \%$ ), menstrual irregularities (14 cases or $8.9 \%$ ) and ascites / abdominal distension (12 cases or $7.6 \%$ ). Among 157 cases, a mere 20 cases were bilateral, most of which (17 out of 20 cases or $85 \%$ ) were surface epithelial tumors, 2 cases were germ cell tumors and 1 metastatic tumor. Of the 17 cases of surface epithelial tumors, 9 cases belonged to serous category, 7 cases were mucinous tumors and single case of transitional cell carcinoma. None of the sex cord stromal tumors were bilateral.

The largest tumor on gross (25 $\mathrm{cm}$ in diameter) belonged to mucinous category and smallest tumor $(1.5 \mathrm{~cm}$ in diameter) was a transitional cell carcinoma. Among Surface epithelial tumors, serous tumors had a smaller mean diameter $(8.88 \mathrm{~cm})$ when compared to mucinous tumors with a mean diameter of $12.08 \mathrm{~cm}$. The single cases of benign Brenner tumor and Clear cell Carcinoma [Figure I \& II] were $15 \mathrm{~cm}$ in diameter each. On the other hand Transitional cell carcinomas [Figure III] and Endometrioid carcinomas [Figure IV \& V] were smaller with mean diameters of $4.25 \mathrm{~cm}$ and $6.6 \mathrm{~cm}$ respectively. Among Germ cell tumors, the malignant types that is Dysgerminomas and Immature teratomas had larger mean diameters of $13.2 \mathrm{~cm}$ and $12.5 \mathrm{~cm}$ respectively whereas the benign Germ cell tumor that is Mature teratomas [Figure VI] had a smaller mean diameter of $8.55 \mathrm{~cm}$. The Sex cord stromal tumors also had variable sizes with the largest one being a Sertoli Leydig cell tumor of diameter $17 \mathrm{~cm}$ while the single case of Thecoma was $8 \mathrm{~cm}$ in diameter. The 6 cases of Granulosa cell tumor had a mean diameter of $10.66 \mathrm{~cm}$. The metastatic tumors (4 cases) were smaller in size ( $8.87 \mathrm{~cm}$ in average diameter).

Out of the 157 tumors, 100 (63.69\%) were cystic, 29 (18.47\%) were solid and $28(17.83 \%)$ were solid cystic. None of the benign and borderline serous tumors were purely solid. Malignant serous tumors had variable appearances. Mucinous tumors were 


\section{JMSCR Vol||04||Issue||12||Page 15040-15047||December}

mostly cystic in appearance. Among germ cell tumors, all dysgerminomas (5 cases) were purely solid with no cystic component and none of the teratomas (both mature and immature) were purely solid. 22 cases of mature cystic teratoma were purely cystic while 5 cases had both components. Laterality and gross features of specific histologic types have been discussed in Table 1.

On histopathologic evaluation, amongst total 157 cases, 90 cases $(57.32 \%)$ of ovarian tumors were benign, 11 cases $(7 \%)$ were borderline and 56 cases $(35.66 \%)$ were malignant. The distribution of tumors is represented in Table 2. Among benign ovarian tumors, serous tumors were the commonest $(39.32 \%)$ followed by mature cystic teratomas $(28.88 \%)$ and mucinous cystadenoma (28.88\%). 1 case each of Thecoma and Brenner tumor were noted. Amongst borderline tumors, borderline mucinous tumor was commonest $(63.63 \%)$ followed by borderline serous tumor $36.36 \%$. Amongst the malignant ovarian tumors, serous carcinomas were the commonest tumor (26 cases or $46.42 \%$ ) followed by Granulosa cell tumor ( 6 cases or $10.71 \%$ ).

On histologic typing, Surface epithelial tumors were commonest $(70.07 \%)$ followed by Germ cell tumors $(22.29 \%)$. Sex cord stromal tumors $(5.09 \%)$ and metastatic tumors $(2.55 \%)$ were the less common categories. Serous cystadenoma 35 $(31.81 \%)$ was the commonest tumor among the surface epithelial stromal tumors followed by malignant serous tumors and benign mucinous tumors $26(23.63 \%)$. Among germ cell tumors, mature cystic teratomas constituted $77.14 \%$ cases followed by malignant germ cell tumor $22.85 \%$. Out of total 8 cases of Sex Cord Stromal tumors, 6 cases $(75 \%)$ were of granulosa cell tumor and one case each $(12.5 \%)$ of Sertoli Leydig cell tumor and Thecoma.

Table 1 - Gross features and laterality of ovarian tumors

\begin{tabular}{|l|l|c|c|c|c|c|c|c|c|}
\hline $\begin{array}{l}\text { Sr } \\
\text { No. }\end{array}$ & Histologic type & $\begin{array}{l}\text { Total } \\
\text { cases }\end{array}$ & Bilateral & \multicolumn{2}{|c|}{ Unilateral } & \multicolumn{2}{l|}{$\begin{array}{l}\text { Average } \\
\text { diameter }\end{array}$} & \multicolumn{3}{|c|}{ Gross features } \\
\hline & & & & L & R & & Solid & Cystic & Both \\
\hline 1 & Benign serous & 35 & 02 & 24 & 09 & 8.31 & - & 32 & 3 \\
\hline 2 & Borderline serous & 04 & 01 & 02 & 01 & 10.75 & - & 04 & - \\
\hline 3 & Malignant serous & 26 & 06 & 08 & 12 & 7.59 & 09 & 12 & 06 \\
\hline 4 & Benign mucinous & 26 & 06 & 12 & 08 & 11.52 & 01 & 20 & 04 \\
\hline 5 & Borderline mucinous & 07 & 01 & 02 & 04 & 13.71 & - & 07 & - \\
\hline 6 & Malignant mucinous & 03 & - & 02 & 01 & 11.00 & - & 03 & - \\
\hline 7 & Benign Brenner & 01 & - & - & 01 & 15 & 01 & - & - \\
\hline 8 & Transitional cell carcinoma & 02 & 01 & - & 01 & 4.25 & 01 & - & 01 \\
\hline 9 & Clear cell carcinoma & 01 & - & - & 01 & 15 & - & - & 01 \\
\hline 10 & Endometrioid carcinoma & 05 & - & 03 & 02 & 6.6 & 02 & - & 03 \\
\hline 11 & Dysgerminoma & 05 & - & 05 & - & 13.2 & 05 & - & - \\
\hline 12 & Immature teratoma & 03 & - & 01 & 02 & 12.5 & - & - & 03 \\
\hline 13 & Mature cystic teratoma & 27 & 02 & 16 & 09 & 8.55 & - & 22 & 05 \\
\hline 14 & Granulosa cell tumor & 06 & - & 03 & 03 & 10.66 & 04 & - & 02 \\
\hline 15 & Thecoma & 01 & - & 01 & - & 8.0 & 01 & - & - \\
\hline 16 & Sertoli Leydig cell tumor & 01 & - & 01 & - & 17 & 01 & - & - \\
\hline 17 & Metastatic tumors & 04 & 01 & 03 & - & 8.87 & 04 & - & - \\
\hline
\end{tabular}




\section{JMSCR Vol||04||Issue||12||Page 15040-15047||December}

Table 2- Incidence of various Histological Types of Ovarian Tumors

\begin{tabular}{|l|c|c|c|c|c|}
\hline Sr. No & Histologic subtypes & $\begin{array}{c}\text { Benign } \\
\mathrm{n}(\%)\end{array}$ & $\begin{array}{c}\text { Borderline } \\
\mathrm{n}(\%)\end{array}$ & $\begin{array}{c}\text { Malignant } \\
\mathrm{n}(\%)\end{array}$ & $\begin{array}{c}\text { Total } \\
\mathrm{n}(\% \text { of all tumors })\end{array}$ \\
\hline 1 & Surface Epithelial Tumors & $62(56.36)$ & $11(10)$ & $37(33.63)$ & $110(70.07)$ \\
\hline 2 & Germ Cell Tumors & $27(77.14)$ & - & $08(22.85)$ & $35(22.29)$ \\
\hline 3 & Sex-Cord Stromal Tumors & $01(12.5)$ & - & $07(87.5)$ & $08(5.09)$ \\
\hline 4 & Metastatic Tumors & - & - & $04(100)$ & $04(2.55)$ \\
\hline \multicolumn{7}{r|}{ Total } & $90(57.34)$ & $11(7)$ & $56(35.66)$ & $157(100)$ \\
\hline
\end{tabular}

Table 3- Comparison of most common malignant tumor of ovary in various parts of Asia

\begin{tabular}{|l|c|c|}
\hline Our study & Maharashtra, India & Serous cystadenocarcinoma \\
\hline Mankar et al & Maharashtra, India & Serous cystadenocarcinoma \\
\hline Kant et al & Jammu and Kashmir, India & Mucinous cystadenocarcinoma \\
\hline Swamy et al & Nepal & Granulosa cell tumor \\
\hline Yasmin et al & Pakistan & Endometrioid carcinoma \\
\hline
\end{tabular}

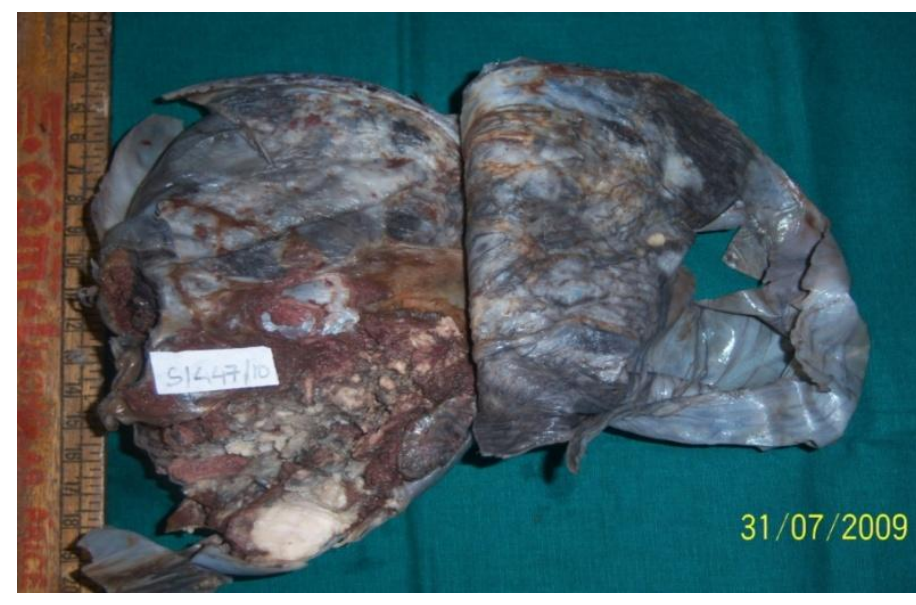

Fig I : Clear Cell Carcinoma of Ovary : Solid and Cystic Tumour With Areas of Haemorrhage and Necrosis.

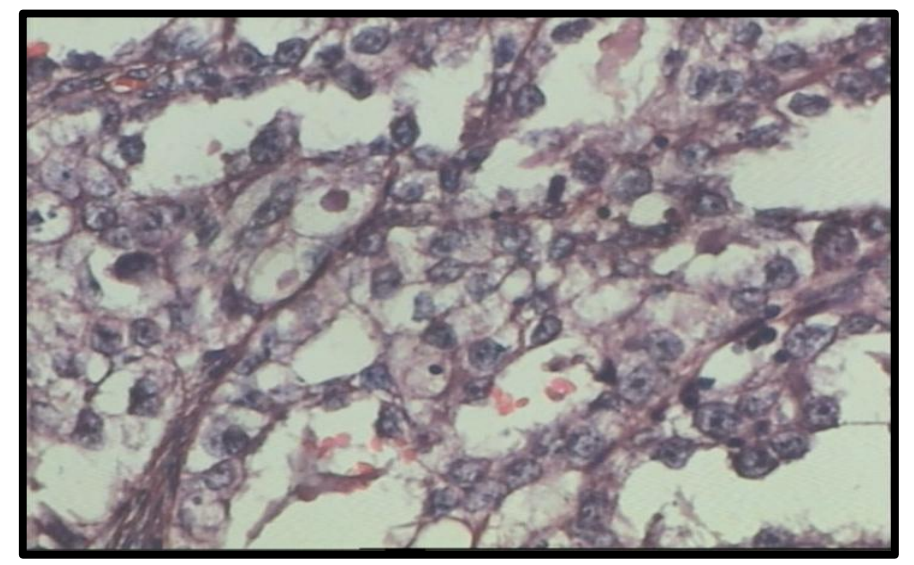

Fig II: Clear cells with pink eosinophilic hyaline globules in cytoplasm

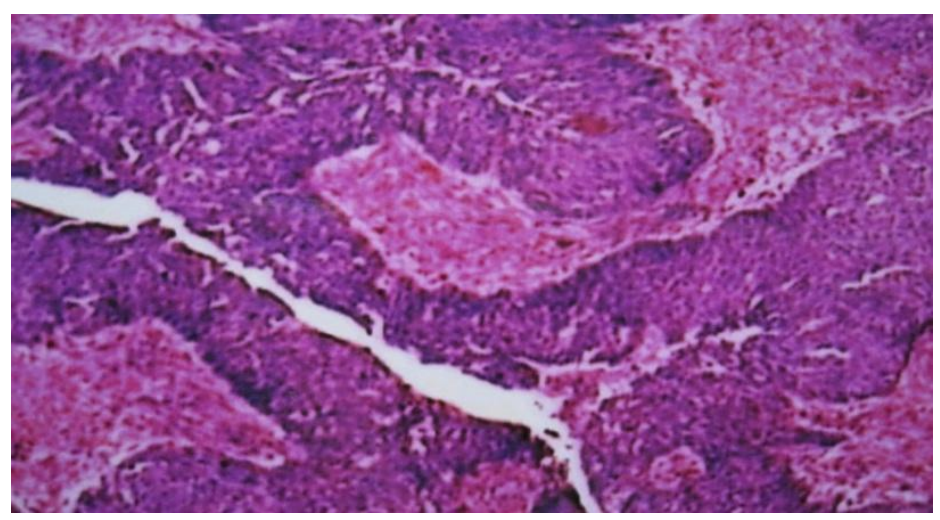

Fig III : Transitional Cell Carcinoma (40x)

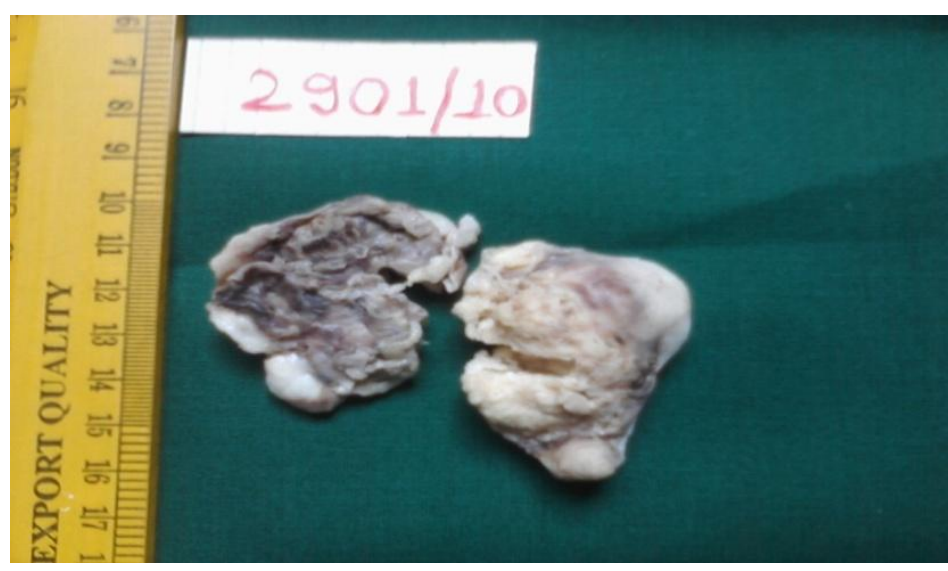

Fig IV: Endometrioid Carinoma of Ovary : Solid Greyish White With Areas of Haemorrhage And Necrosis. 


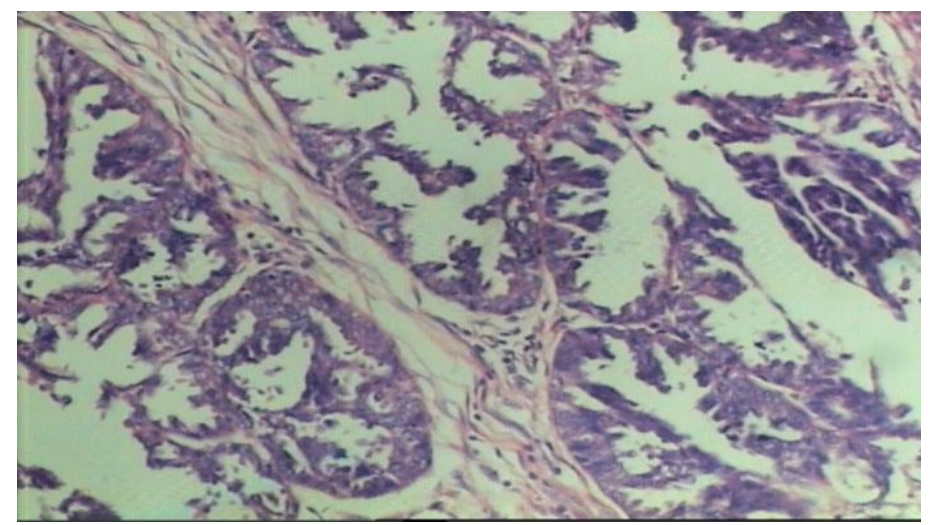

Fig V: Endometrioid Adenocarcinoma ( $10 \mathrm{X}$ ): Showing Tumour Arranged In Glandular Pattern Seperated By Fibrocollagenous Septae

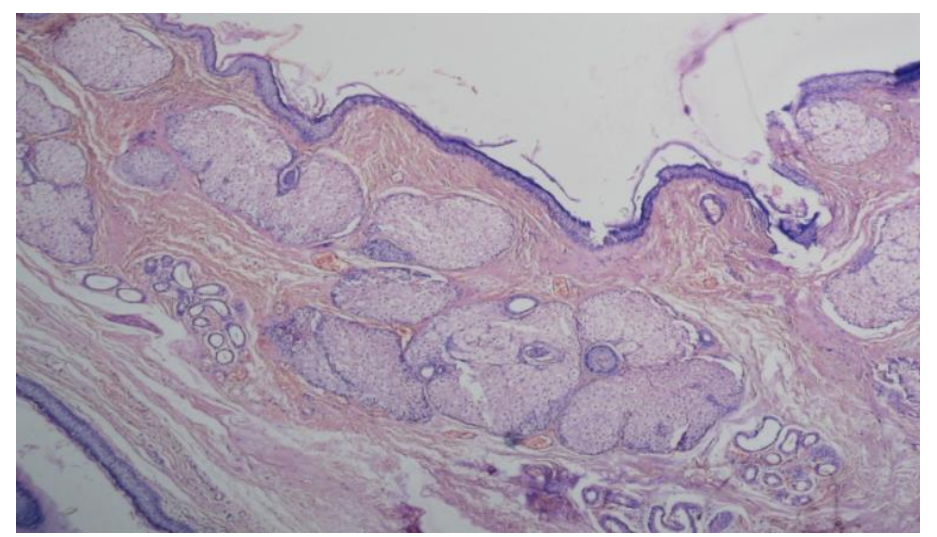

Fig VI: Mature Cystic Teratoma (Dermoid Cyst)(10x)-Cyst Lined By Stratified Squamous Epithelium With Underlying Skin Appendages.

\section{DISCUSSION}

Ovarian neoplasms are the most common tumors of female genital tract ${ }^{1}$, taking a significant toll in developing nations due to non specificity of symptoms and lack of regular clinical check-ups. The patients consequently present at advanced stages of the disease.

The most common clinical symptom in our study was lower abdominal pain (68.78\% of cases). $84 \%$ patients in a study conducted in $\mathrm{Nepal}^{3}$ and $76 \%$ patients in a study conducted in Satara ${ }^{4}$ presented with the same complaint. Other common symptoms were also similar to our study that is lump in abdomen, ascites/ abdominal distension and menstrual irregularities. On the contrary, studies conducted in western countries noted abdominal distension as the most common symptom. ${ }^{5-8}$ Another point to be noted in our study was that, a single case of dermoid cyst (out of total 157 cases) was diagnosed incidentally whereas $10.5 \%$ cases in study by Kayastha et al (in Nepal) ${ }^{3}$ and $14.98 \%$ cases in study by Mankar et $\mathrm{al}^{4}$ (in Maharashtra) were diagnosed incidentally. This can be attributed to the more timely consultation, investigation and follow up in our set up.

Age range in our study was 11-72 years, with a mean of 41.2 years. Age range was in concordance with studies conducted in Jammu \& $\operatorname{Kashmir}^{9}$ (15-70 years), Nepal ${ }^{3}$ (18-70 years) and Maharashtra $^{4}$ (14 to 76 years). The peak incidence in our study occurred in 21-40 years age group and agreed well with study by Pilli GS et $\mathrm{al}^{10}$, a study conducted in Belgaum. In this age group in our study, most cases were of benign tumors (57 cases) followed by malignant tumors (20 cases) and borderline tumors (4 cases). The second most common age group was 41-60 years which accounted for 18 benign, 24 malignant and 5 borderline tumors. Mean ages for benign, borderline and malignant categories were 37, 49.6 and 41.2 years respectively. As is evident from this data, malignant tumors were way more common in and above $4^{\text {th }}$ decade of life and a greater age was indicative of more sinister tumors. Mean age for surface epithelial tumors, germ cell tumors, sex cord stromal cell tumors and metastatic tumors was 44.4 years, 23.6 years, 46.7 years and 46.3 years respectively. The mean age group was noticeably lesser for Germ cell tumors, finding in concordane with Kos et al. ${ }^{11}$

$12.7 \%$ (20 out of 157) cases in our study were bilateral. $12.6 \%, 11.67 \%$ and $8.86 \%$ cases were bilateral in studies by Kayastha et $\mathrm{al}^{3}$, Mankar et $\mathrm{al}^{4}$ and Sharma et $\mathrm{al}^{12}$ respectively (studies conducted in various states of India). 17 out of 20 bilateral cases were surface epithelial tumors (9 serous, 7 mucinous and 1 transitional cell carcinoma). Among bilateral germ cell tumors (2 cases), both were mature cystic teratomas. 1 out of total 4 metastatic cases was bilateral while none of the sex cord stromal tumors presented bilaterally. The most significant finding in this aspect of 
study was that $85 \%$ of bilateral tumors were Surface epithelial tumors and also when bilateral tumors were present in young patients, the diagnosis was found to be mature cystic teratoma. Coming to gross examination of tumors, our study noted greater diameters $(>10 \mathrm{~cm})$ for Mucinous tumors $(12.08 \mathrm{~cm})$, Clear cell carcinoma $(15 \mathrm{~cm})$ and malignant Germ cell tumors $(12.8 \mathrm{~cm})$. The diameter of Sex cord stromal tumors was also $>10 \mathrm{~cm}$ for most cases. The mean diameter was however smaller for Serous tumors $(8.88 \mathrm{~cm})$, even for malignant tumors $(7.59 \mathrm{~cm})$ which was the most common subtype among malignant tumors in our study as discussed previously. Hence, this finding of smaller malignant serous tumors in our study can be attributed to early detection and diagnosis in our set up. The other tumors with smaller diameters were Transitional cell carcinomas, Endometrioid carcinomas and Metastatic tumors. As per study by Hashmi et $\mathrm{al}^{13}$, the malignant tumors had a greater mean diameter. Both malignant surface epithelial tumors and germ cell tumors had a mean diameter $>10 \mathrm{~cm}$. Sex cord stromal tumors were generally large in size in this study (both benign and malignant $>10 \mathrm{~cm}$ in diameter). Smaller tumors $(<10 \mathrm{~cm}$ in diameter) belonged to categories of benign surface epithelial tumors, benign germ cell tumors and metastatic malignancies. These findings are thus in agreement with our study. A study on germ cell tumors by Kos et $\mathrm{al}^{11}$ noted that the diameter was $<10 \mathrm{~cm}$ for $94.5 \%$ of teratomas. In our study, there were a total of 30 teratomas ( 27 benign and 3 malignant). The mean diameter for the 27 benign teratomas $(90 \%$ of all teratomas) was $8.55 \mathrm{~cm}$, hence concordant with findings of Kos et al.

On cut section, out of 157 tumors, 100 were cystic, 29 were soilid and 28 were solid cystic. None of the benign and borderline serous tumors were purely solid. Malignant serous tumors had variable appearances. Mucinous tumors were mostly cystic in appearance. Among germ cell tumors, all dysgerminomas (5 cases) were purely solid with no cystic component and none of the teratomas (both mature and immature) were purely solid. 22 cases of mature cystic teratoma were purely cystic while 5 cases had both components. Findings were concordant with study by Sharma et $\mathrm{al}^{12}$, wherein out of 102 ovarian tumors, 46 cases (45.09\%) were cystic, 42 cases $(41.17 \%)$ were solid cystic and 14 cases $(13.74 \%)$ were predominantly solid tumors. Most of the benign tumors presented as cystic masses.

On histopathological examination, amongst 157 cases, 90 were benign $(57.32 \%)$, 11 cases borderline (7\%) and 56 cases were malignant $(35.66 \%)$. The findings in our study were quite in agreement with some of the studies conducted in Asia. Mankar et $\mathrm{al}^{4}$ (also conducted the study in Maharashtra) reported an incidence of $63.04 \%, 5.84 \%$ and $31.12 \%$ for benign, borderline and malignant tumors respectively while Ahmad et $\mathrm{al}^{14}$ (a study in Pakistan) reported an incidence of $59.18 \%, 0.2 \%$ and $40.81 \%$. Other studies by Pilli et $\mathrm{al}^{10}$ and Gupta et $\mathrm{al}^{15}$ reported figures of $75.2 \%$ and and $72.9 \%$ respectively for benign tumors which is closer to figures reported by western nations that is $75-80 \% .{ }^{16}$ Hence, overall the incidence of benign tumors is lower in our study. However, the proportion of borderline tumors (7\%) in our study was considerably higher than in other studies wherein, the incidence was reported between $0.2 \%-4.1 \%$. The study by Mankar et $\mathrm{al}^{4}$ (also conducted in the state of Maharashtra) however reports an incidence of $5.84 \%$ for borderline tumors which is closest to our finding, hence can be considered as a geographical variation.

Among benign tumors, our study reports serous cystadenoma as the most common benign tumor (39.32\%) followed by mucinous cystadenoma and mature cystic teratoma ( $28.88 \%$ each). Study in Jammu and Kashmir by Kant et $\mathrm{al}^{9}$ also reported a similar finding of maximum number of serous cystadenomas $(22.5 \%)$ followed by mucinous cystadenomas $(19.4 \%)$. Shah et $\mathrm{al}^{17}$ and Thanikasalam et $\mathrm{al}^{18}$ have also reported serous cystadenoma as the most common benign tumor of ovary. The finding however differs from another study in same geographic area conducted by Mankar et $\mathrm{al}^{4}$ that reported mucinous cystadenoma as the most common benign tumor. All these studies reported a lower incidence of mature cystic teratomas 
than in our study. Among borderline tumors, our study reports 7 cases of mucinous category $\& 4$ cases of serous category. Most other studies report a similar finding of greater incidence of mucinous borderline tumors although the overall incidence of borderline tumors was low. However, the study by Mankar et el ${ }^{4}$ that reported higher incidence of borderline tumors similar to our study, found an equal incidence of serous and mucinous borderline tumors. Hence, the incidence of borderline mucinous tumors in our study is significantly higher than in other studies.

Amongst malignant tumors, serous cystadenocarcinoma $(46.42 \%)$ was most common followed by granulosa cell tumor $(10.71 \%)$. The finding is in agreement with another study conducted in state of Maharashtra wherein serous cystadenocarcinoma outnumbered all other tumors. ${ }^{4}$ The data in this regard is quite variable depending upon the geographic region as depicted in Table 3. Study by Kant et $\mathrm{al}^{9}$ in Jammu \& Kashmir reports mucinous cystadenocarcinoma as commonest, study by Swamy et $\mathrm{al}^{19}$ in Nepal reports granulosa cell tumor as commonest whereas Yasmin et $\mathrm{al}^{20}$ observed endometrioid carcinoma as most common tumor in Pakistan.

Coming to histologic subtypes; the finding of surface epithelial tumors as the most common tumor (70.07\%) followed by germ cell tumors $(22.29 \%)$, Sex cord stromal tumors $(5.09 \%)$ and metastatic tumors $(2.55 \%)$, in our study is quite concordant with other studies in Asian countries. The studies in Western nations $^{21}$ reported Germ cell tumors as the most common tumor in benign category and surface epithelial tumors as the most common tumor in malignant category whereas in our scenario surface epithelial tumors have a distinctly higher incidence as compared to other subtypes, be it benign or malignant. Incidence of metastatic tumors to ovary was lower than in other study $(2.55 \%)$, as in other studies, that is $3.1 \%$ in study by Kant et $\mathrm{al}^{9}, 5 \%$ in Powari et $\mathrm{al}^{22}$. However, Pudassini et $\mathrm{al}^{23}$ reported a slightly higher percentage of $6.9 \%$.

\section{CONCLUSION}

The study was conducted in a developing nation on a sample size of 157 cases. Lower abdominal pain was the most common symptom whereas incidentally diagnosed ovarian tumor was uncommon. Peak age group was $21-40$ years. $12.7 \%$ tumors were bilateral, belonged most commonly to surface epithelial tumor category. Mucinous tumors, malignant Germ cell tumors and Sex cord stromal tumors were large ( $>10$ $\mathrm{cm}$ average diameter) whereas Serous tumors, benign Germ cell tumors and Metastatic tumors were smaller in size. Grossly, most tumors were cystic. Only rarely, benign tumors were purely solid. On histopathology, benign tumors were commonest although lower in percentage than western countries. Incidence of borderline tumors especially mucinous type and malignant tumors were higher in our study than in other parts of the world. Serous cystadenocarcinoma was the most common malignant tumor, an important geographical variation.

\section{REFERENCES}

1. Hennessy BT, Suh GK, Markman M. Ovarian Cancer. In: Kantarjian HM, Wolff RA, Koller CA, editors. The MD Anderson Manual of Medical Oncology.

2. Mc Cluggage WG. My approach to and thoughts on the typing of ovarian carcinomas. J Clin Pathol. 2008;61:15263.

3. Kayastha S. Study of ovarian tumors in Nepal Medical College Teaching Hospital. Nepal Med Coll J. 2009;11:200-2.

4. Mankar DV, Jain GK. Histopathological profile of ovarian tumours: A twelve year institutional experience. Muller J Med Sci Res. 2015;6:11.

5. Bankhead CR, Collin SC, StokesLampard H. Identifying symptoms of ovarian cancer: a qualitative and quantitative study. Brit J Obstet Gynaecol 2008; 115: 1008 -14.

6. Goff B, Mandel L, Melancon $\mathrm{CH}$ et al. Frequency of symptoms of ovarian cancer 
in women presenting to primary care clinics. J Amer Med Assoc 2004; 291: 2705-12.

7. Olson SH, Migone L, Nakraseive $\mathrm{C}$ et al. Symptoms of ovartian cancer. Obstet Gynaecol 2001; 90: 75-82.

8. Vine MF, Callingaert B, Berchuk A. Characterization of prediagnostic symptoms among primary epithelial ovarian cancer cases and controls. Gynecol Oncol 2003; 90: 75-82.

9. Kant R, Rather S, Rashid S. Clinical and histopathological profile of patients with ovarian cyst presenting in a tertiary care hospital of Kashmir, India. Int $\mathbf{J}$ of Reproduction, Contraception, Obstet and Gynaecol 2016; 5(8):2696-270.

10. Pilli GS, Suneeta KP, Dhaded AV, Yenni VV. Ovarian tumours: A study of 282 cases. J Indian Med Assoc 2002;100:420, 423-24, 427.

11. Kos M, Nikic J, Lenicek T. Ovarian teratoma in routine biopsy material during a five year period. Acta Clin Croat 2016; 55:265-70

12. Sharma I, Chaliha T. Histopathological Patterns of Germ cell tumors of ovary in a tertiary level hospital. Int $\mathbf{J}$ of Pharmaceutical Science Invention 2014; 3(10): 14-24.

13. Hashmi A, Bhagwani A, Edhi $M$ et al. Clinicopathologic features of ovarian neoplasms with emphasis on borderline ovarian tumors: an institutional perspective 2016; 9:205.

14. Ahmad Z, Kayani N, Hasan SH, Muzaffar S, Gill MS. Histological pattern of ovarian neoplasm. J Pak Med Assoc 2000;50:4169.

15. Gupta N, Bisht D, Agarwal AK, Sharma VK. Retrospective and prospective study of ovarian tumours and tumour-like lesions. Indian $\mathrm{J}$ Pathol Microbiol 2007;50:525-7.
16. Scully RE, Young RH, Clement PB. Atlas of Tumour Pathology.Tumours of the ovary, maldeveloped gonads, fallopian tube, and broad ligament. 3rd series, Fascicle 23, Washington DC. Armed Force Institute of Pathology, 1999; 1-168.

17. Shah S, Hishikar VA. Incidence and management of ovarian tumours. Bombay Hospital J 2008; 50:30-3.

18. Thanikasalam K, Ho CM, Adeed N, Shahidan MN, Azizah WK. Pattern of ovarian tumours among Malaysian women at general hospital, Kuala Lumpur. Med J Malaysia 1992;47:139-46.

19. Swamy GG, Satyanarayana N. Clinicopathological analysis of ovarian tumors -- a study on fi ve years samples. Nepal Med Coll J 2010;12:221-3.

20. Yasmin S, Yasmin A, Asif M. Clinicohistological pattern of ovarian tumours in Peshawar region. J Ayub Med Coll Abbottabad 2008;20:11-3.

21. Koonings PP, Campbell K, Mishell DR Jr, Grimes DA. Relative frequency of primary ovarian neoplasms: a10 year review. Obstet Gynaecol 1989; 74: 921-26.

22. Powari M, Dey P, Gupta SK, Saha S. Metastatic tumors of the ovary: a clinicopathological study. Indian J Pathol Microbiol. 2003;46:412-5.

23. Pudasaini S, Lakhey M, Hirachand S, Akhter J, Thapa B: A study of ovarian cyst in a tertiary hospital of Kathmandu valley. Nepal Med Coll J. 2011;13(1):39-41. 